\title{
Maintenance requirements for methionine and cysteine, and threonine for poultry
}

\author{
M.A. Bonato ${ }^{\#}$, N.K. Sakomura, J.C. Siqueira, J.B.K. Fernandes \& R.M. Gous ${ }^{1}$ \\ Department of Animal Science, Faculty of Agriculture and Veterinary Sciences - UNESP, Jaboticabal, SP, Brazil \\ ${ }^{1}$ Animal and Poultry Science, University of KwaZulu-Natal, Scottsville 3209, South Africa
}

Copyright resides with the authors in terms of the Creative Commons Attribution 2.5 South African Licence.

See: .http://creativecommons.org/licenses/by/2.5/za

Condition of use: The user may copy, distribute, transmit and adapt the work, but must recognise the authors and the South African Journal of Animal Science.

\begin{abstract}
This study aimed to estimate the methionine \& cystine (M\&C), and threonine (THR) requirements for maintenance of adult roosters differing in liveweight and body composition, and to estimate the concentrations of $\mathrm{M} \& \mathrm{C}$ and threonine in 'ideal' protein for maintenance. Five metabolism trials were conducted using 42 mature Bovans White (in trials 1 and 3) and 42 Cobb (in trials 2 and 4) roosters. In the first two trials, designed to measure the $M \& C$ requirements for maintenance, the $M \& C$ content in the diets ranged from 0 to $138 \mathrm{mg} / \mathrm{kg} \mathrm{d}\left(687 \mathrm{mg} / \mathrm{BP}_{\mathrm{m}}{ }^{0.73} / \mathrm{d}\right)$ for the Bovans White, and from 0 to $64 \mathrm{mg} / \mathrm{kg} \mathrm{d}(346$ $\mathrm{mg} / \mathrm{BP}_{\mathrm{m}}{ }^{0.73} / \mathrm{d}$ ) for the Cobb strain, respectively (where $\mathrm{BP}_{\mathrm{m}}$ is mature body protein weight). In trials 3 and 4 in which the THR requirement for maintenance was measured, the THR levels ranged from 0 to $127 \mathrm{mg} / \mathrm{kg} \mathrm{d}$ $\left(624 \mathrm{mg} / \mathrm{BP}_{\mathrm{m}}{ }^{0.73} \cdot \mathrm{u} / \mathrm{d}\right)$ and from 0 to $106 \mathrm{mg} / \mathrm{kg} \mathrm{d}\left(584 \mathrm{mg} / \mathrm{BP}_{\mathrm{m}}{ }^{0.73} \cdot \mathrm{u} / \mathrm{d}\right)$ for the two strains, respectively. Excreta were collected in trays, weighed, homogenized, dried and ground and the nitrogen contents of excreta and diets were then determined. The M\&C requirement for maintenance was estimated as $19 \mathrm{mg} / \mathrm{kg}$ empty body weight (EBW) $/ \mathrm{d}, 26 \mathrm{mg} / \mathrm{kg} \mathrm{EBW}{ }^{0.75} / \mathrm{d}$ or $87 \mathrm{mg} / \mathrm{BP}_{\mathrm{m}}{ }^{0.73} / \mathrm{d}$. The maintenance requirement for THR was estimated as $17 \mathrm{mg} / \mathrm{kg}$ EBW/d, $22 \mathrm{mg} / \mathrm{kg} \mathrm{EBW}{ }^{0.75} / \mathrm{d}$ or $76 \mathrm{mg} / \mathrm{BP}_{\mathrm{m}}{ }^{0.73} / \mathrm{d}$. The concentration of $\mathrm{M} \& \mathrm{C}$ in 'ideal' protein for maintenance was estimated as 11 , and THR, $9.4 \mathrm{~g} / \mathrm{kg}$ body protein.
\end{abstract}

Keywords: Bovans White, Cobb, ideal protein

${ }^{\#}$ Corresponding author: melinabonato@ig.com.br

\section{Introduction}

A bird can be said to be in a state of nitrogen (N) maintenance when the intake is exactly equal to the sum of its losses, thereby keeping the body N content constant (Owens \& Pettgrew, 1989; Sakomura \& Coon, 2003; Sakomura \& Rostagno, 2007). At maintenance, metabolic processes occur that result in losses of proteinaceous material from the body which must be replaced by the diet. Moughan (2003) listed these processes as losses of amino acids via skin and hair (and feathers in the case of poultry), losses of $\mathrm{N}$ of amino acid origin in urine reflecting inefficiency in the process of body protein turnover, basal gut endogenous amino acid losses (mainly mucus, bile, desquamated cells), the irreversible loss of amino acids in synthesizing essential non-amino acid nitrogenous metabolites (e.g. creatinine), irreversible chemical alterations of amino acids (e.g. lysine to hydroxyl lysine) and the loss of free amino acids in the urine. To maintain this $\mathrm{N}$ balance, amino acids must be supplied at the same rate as they are lost through metabolism, secretion or excretion from the body (Sakomura \& Rostagno, 2007). Where the amino acids required for maintenance are supplied in exactly the correct proportions in the dietary protein, the so-called 'ideal' protein, the amount of protein required for maintenance would be minimized.

For a rapidly growing animal the amino acids required for maintenance make up only a small proportion of the total daily amino acid requirement, whereas in the laying and broiler breeder hen this situation is reversed. Certain dietary essential amino acids are required disproportionately (e.g. cysteine loss in skin, hair and feathers; and threonine loss in gut endogenous protein) (Moughan, 2003). Methionine \& 
cysteine $(\mathrm{M} \& \mathrm{C})$ and threonine are essential for body maintenance, being part of metabolic processes, and also for cell synthesis and renewal.

Cysteine participates in the synthesis of keratin in feathers. In the case of a cysteine deficiency, nutrient deposition in the breast muscle may be reduced because keratin synthesis is a priority (Wylie et al., 2001). According to Lewis (2003), in a study with pigs, the proportion of M\&C that can be provided by cystine is much greater for maintenance than for new tissue accretion, and consequently the cystine replacement value increases as the animal matures and maintenance becomes a larger proportion of the total amino acid requirement.

Threonine is important not only for protein deposition, but also for mucin production and digestive processes (Ball et al., 1999). Mucins are relatively resistant to digestion and so endogenous losses of these amino acids can be high, being dependent on the type of dietary ingredients used as these may induce gut atrophy and increase mucin secretion (Bequette, 2003).

Several authors have studied the requirements of $\mathrm{M} \& \mathrm{C}$ for maintenance and growth of animals (Leveille et al., 1960; Baker et al., 1966; Graber \& Baker, 1971; Edwards \& Baker, 1999; Heger et al., 2002; Kalinowski et al., 2003); however, the results of studies with maintenance requirement for M\&C are variable (Kalinowski et al., 2003). This can be attributed to the use of different experimental methods, and also the category of experimental birds (Sakomura \& Rostagno, 2007).

According to Owens \& Pettigrew (1989) amino acid requirements for maintenance can be measured in both growing and adult animals, based on the relationship between amino acid intake and body $\mathrm{N}$ retention. However, according to Burnham \& Gous (1992) the interpretation of results from experiments with growing animals should be done with caution because of the variation that occurs in growth and body composition between animals during the trial, which makes it difficult to decide on the proportion of the test amino acid intake that should be apportioned to maintenance during the trial. Also, the body composition of birds and animals such as pigs change over time because the proportions of body and integument change (Nitsan et al., 1981; Fisher \& Scougal; 1982, Kyriazakis et al., 1993). Thus, evaluations using adult males are more accurate because the total amino acid requirements of these birds are associated only with maintenance and not with growth and/or reproduction (Owens \& Pettigrew, 1989; Siqueira, 2009) and their mature contents of body and feather protein have been reached, with no further changes in their relative proportions being likely.

Another aspect to be taken into account is the scale on which maintenance requirement is expressed. Most studies consider amino acid requirements for maintenance in terms of fasting body weight ( $\mathrm{mg} / \mathrm{kg} \mathrm{d})$ or metabolic body weight $\left(\mathrm{mg} / \mathrm{kg}^{0.75} \mathrm{~d}\right)$. However, Emmans \& Fisher (1986) have argued that amino acid requirements for maintenance are more closely related to body protein content because they are not required for maintaining body lipid, and proposed that maintenance requirements for both protein and energy should be expressed in terms of a unit of maintenance $\left(\mathrm{BP}_{\mathrm{m}}{ }^{0.73} \cdot \mathrm{u}\right)$ where $\mathrm{BP}_{\mathrm{m}}$ is the mature body protein weight and $\mathrm{u}$ is the degree of maturity (weight of body protein at time $\mathrm{t} / \mathrm{BP}_{\mathrm{m}}$ ) of the bird. Since body lipid content varies considerably depending on the way that the bird is fed (Gous et al., 1984; 1990) it is more appropriate to express amino acid requirements for maintenance based on body protein content (Nonis \& Gous, 2008).

To avoid wastage and reduce environmental pollution, poultry nutritionists should be aiming at reducing the amount of protein that is fed in excess of the requirements of poultry. This can only be achieved by defining more accurately the amount of each essential amino acid that is required for maintenance and for growth. Because there is still some doubt in the literature of the amount of M\&C and threonine required for maintenance of poultry, the study reported here was designed to address these deficiencies.

\section{Materials and Methods}

Five metabolism assays were conducted in the poultry facilities of the Department of Animal Science, Faculty of Agriculture and Veterinary Sciences - UNESP, Jaboticabal, SP, Brazil to determine the M\&C and threonine (THR) requirements for maintenance of broiler breeder males using the methodology described by Nonis \& Gous (2008). Although only two assays were planned for each amino acid, a third assay was performed with THR because of an unacceptably high variation in the results from Bovans White roosters in the first assay.

To test the argument that amino acids for maintenance should be expressed in terms of body protein content and not body weight, two strains of poultry were used. The Bovans White males used had mature 
weights of $2.02 \pm 0.2$ in the M\&C trials, and $2.11 \pm 0.2 \mathrm{~kg}$ in the THR trials, whilst the corresponding weights of the Cobb males were $5.54 \pm 0.6$ and $5.78 \pm 0.7 \mathrm{~kg}$, respectively. The birds from each strain used in each trial were selected according to their weight, so that all treatments started with birds of similar average weight. For each amino acid, 42 birds of each strain were used, but different birds were used for each amino acid.

The roosters were housed individually in metabolism cages $(0.4 \times 0.5 \times 0.6 \mathrm{~m})$, each being supplied with a nipple drinker and feeder. Each experiment consisted of feeding six diets each containing a different level of the amino acid under test, with six replications of each diet being used. Treatments were randomly allocated between the cages.

Food was removed from the birds two days before starting the trial in order to empty the digestive tract of extraneous protein-containing material. During this period $60 \mathrm{~mL}$ of water with sucrose $(50 \%$ of each) was fed once daily by intubation. On the morning of the third day (first day of the $3 \mathrm{~d}$ balance period) the body weight of each bird was recorded. Every $24 \mathrm{~h}$ during the subsequent $72 \mathrm{~h}(3 \mathrm{~d})$ the birds were fed the experimental diets by intubation. Throughout this period an $\mathrm{N}$-free diet was available ad libitum in each trough. The consumption of this diet was measured over the $72 \mathrm{~h}$ period. Excreta collection commenced 24 $\mathrm{h}$ after the first intubation and ended $24 \mathrm{~h}$ after the last. The weight of excreta voided per bird was quantified.

Two experimental diets were formulated for each strain used in the trial, one being $\mathrm{N}$-free but containing energy, minerals and vitamins as recommended by Rostagno et al. (2005), and the other containing the same levels of ME, minerals and vitamins, but also containing protein, with the test amino acid (M\&C or THR) being first-limiting with a relative deficiency 0.2 below the 'ideal' requirement.

The composition of the four basal diets used to measure the M\&C required for maintenance of the two strains is presented in Table 1 and of those used in the THR trials in Table 2 . The daily allowance fed to the birds by intubation comprised a mixture of $\mathrm{N}$-free and $\mathrm{N}$-containing feeds, and this differed for the two strains. For the Bovans White strain the six diets for both amino acid trials comprised 40, 37.5, 35, 30, 20 and $0 \mathrm{~g}$ of the $\mathrm{N}$-free diet with these amounts being supplemented with the respective $\mathrm{N}$-containing diet to make a total of $40 \mathrm{~g}$, this being their daily allocation. In the case of the Cobb birds, they were fed $60 \mathrm{~g}$ daily by intubation in the M\&C study, and the six feeds in that series were made by blending $60,50,47.5,35,22.5$ and $10 \mathrm{~g}$ of the $\mathrm{N}$-free diet in Table 1 with the $\mathrm{N}$-containing diet to make up the $60 \mathrm{~g}$. In the THR study only $50 \mathrm{~g}$ was fed, the amounts of $\mathrm{N}$-free feed (Table 2) used being 50, 45, 30, 20, 10 and $0 \mathrm{~g}$.

To determine the body composition of birds at the end of each trial three roosters were selected with weights close to the average of the birds used. After being fasted for 24 hours to evacuate the digestive tract the birds were killed by asphyxiation with $\mathrm{CO}_{2}$, weighed and frozen. Subsequently they were homogenized and aliquots were placed in disposable Petri dishes for further chemical analysis.

The excreta produced daily were weighed and kept in a freezer $\left(-20^{\circ} \mathrm{C}\right)$ until the end of the trial. Once thawed, samples from each bird were homogenized using a household blender (RI2008, Walita) adding a known volume of distilled water to obtain a proper consistency, as described by Burnham \& Gous (1992). In this case, the weight corresponding to the volume of distilled water added was added to the total excreta produced. Aliquots were placed in disposable Petri dishes, weighed and frozen again $\left(-20^{\circ} \mathrm{C}\right)$ then vacuum dried $\left(-50{ }^{\circ} \mathrm{C} ;-80 \mathrm{kPa}\right)$ (VLP20, Thermo Fisher) for $72 \mathrm{~h}$. The dried samples were ground in a micro mill (A11 BASIC - IKA, São Paulo) for one minute.

The experimental diets were processed as for the excreta. Feed, excreta and carcass samples were analysed for dry matter, ether extract (for carcasses only) and total $\mathrm{N}$, the latter using the Kjeldahl method as described by AOAC (1990).

Nitrogen $(\mathrm{N})$ balance was calculated as the difference between $\mathrm{N}$ intake and $\mathrm{N}$ excreted. Linear regressions of $\mathrm{N}$ balance on intakes of both $\mathrm{M} \& \mathrm{C}$ and THR expressed in terms of four scales describing the birds used (mg/bird, $\mathrm{mg} / \mathrm{kg}$ EBW d, $\mathrm{mg} / \mathrm{kg} \mathrm{EBW}{ }^{0.75} \mathrm{~d}$ and $\mathrm{mg} / \mathrm{BP}_{\mathrm{m}}{ }^{0.73}$.ud, where EBW is the empty body weight of the bird and $\mathrm{BP}_{\mathrm{m}}$ is the mature body protein content, and $\mathrm{u}$ is the degree of maturity, or $\mathrm{BP} / \mathrm{BP}_{\mathrm{m}}$ ) were obtained. Because the males used in the trial were mature $(u=1)$, in effect the third scale could be regarded as being $\mathrm{mg} / \mathrm{BP}_{\mathrm{m}}{ }^{0.73} \mathrm{~d}$. Based on these equations the digestible amino acid requirement for maintenance was determined as the intake (on each of the three scales) corresponding to a zero $\mathrm{N}$ balance. Statistical analysis was performed for a significance level of up to $5 \%$ using the GLM procedure of the software SAS 9.0 (2002). To compare responses between genotypes and trials within each amino acid tested, use was made of a parallelism test. In this test the differences in constant term and regression coefficient 
Table 1 Composition of basal diets used to determine the methionine \& cysteine requirements for maintenance of two strains of rooster

\begin{tabular}{|c|c|c|c|c|}
\hline \multirow{2}{*}{ Ingredients } & \multicolumn{2}{|c|}{ Bovans White } & \multicolumn{2}{|c|}{ Cobb } \\
\hline & N-Free & With N & N-Free & With N \\
\hline Maize & ----- & 355 & ------- & 581 \\
\hline Soybean meal $45 \%$ & ------ & 480 & ------- & 319 \\
\hline Starch & 400 & ----- & 650 & ------ \\
\hline Rice husk & 120 & ------ & 120 & ------ \\
\hline Sugar & 380 & ------ & 119 & ------- \\
\hline Soybean oil & 22.2 & 73.2 & 32.6 & 43.8 \\
\hline Dicalcium phosphate & 27.0 & 20.8 & 27.0 & 21.4 \\
\hline Limestone & 8.3 & 9.3 & 8.3 & 9.8 \\
\hline Salt & ----- & 8.1 & ------ & 8.0 \\
\hline Potassium chloride & 15.3 & ------ & 15.3 & ------ \\
\hline Sodium bicarbonate & 12.5 & ----- & 12.5 & ------- \\
\hline L-Lysine $\mathrm{HCl}(78.5 \%)$ & ------ & 2.7 & ------- & ------- \\
\hline DL-Methionine (98\%) & ------ & 1.4 & ------- & 0.3 \\
\hline L-Threonine (90.6\%) & ------ & 6.8 & ------ & 0.8 \\
\hline L-Tryptophan (93.3\%) & ----- & 1.6 & ------ & ------ \\
\hline L-Valine $(98 \%)$ & ----- & 9.0 & ------ & 1.2 \\
\hline L-Arginine (93.1\%) & ------ & 5.1 & ------- & ------- \\
\hline L-Isoleucine (98\%) & ----- & 6.4 & ------ & 0.0 \\
\hline L-Leucine $(98.5 \%)$ & ----- & 4.2 & ------ & ------ \\
\hline L-Phenylalanine (98\%) & ------ & 1.0 & & ------- \\
\hline Choline chloride $70 \%$ & 5.0 & 5.0 & 5.0 & 5.0 \\
\hline Vitamin/mineral premix ${ }^{1}$ & 10.0 & 10.0 & 10.0 & 10.0 \\
\hline \multicolumn{5}{|l|}{ Nutrients calculated } \\
\hline Metabolizable energy $(\mathrm{MJ} / \mathrm{kg})$ & 13.0 & 13.0 & 13.0 & 13.0 \\
\hline Crude protein $(\mathrm{g} / \mathrm{kg})$ & $2.1(2.01)^{2}$ & $274(294)$ & $2.1(1.84)$ & $198(204)$ \\
\hline Lysine $^{3}$ & ----- & 15.1 & ------ & 9.31 \\
\hline Methionine \& cysteine & ------ & 7.92 & ------ & 5.85 \\
\hline Tryptophan & ----- & 4.37 & ------ & 2.15 \\
\hline Threonine & ----- & 14.6 & ------- & 7.20 \\
\hline Arginine & ------ & 21.2 & ------ & 11.9 \\
\hline Valine & ----- & 19.4 & ------ & 9.43 \\
\hline Phenylalanine & ----- & 12.6 & ------ & 8.98 \\
\hline Isoleucine & ------ & 16.4 & ------ & 8.09 \\
\hline Leucine & ------ & 23.4 & ------- & 16.3 \\
\hline
\end{tabular}

${ }^{1}$ Content/kg: vit. $\mathrm{A}=12000000 \mathrm{IU}$; vit. $\mathrm{D}_{3}=22000000 \mathrm{IU}$; vit. $\mathrm{E}=30000 \mathrm{mg}$; vit. $\mathrm{B}_{1}=2200 \mathrm{mg}$; vit. $\mathrm{B}_{2}=6000 \mathrm{mg}$, vit. $\mathrm{B}_{6}=3300 \mathrm{mg}$; vit. $\mathrm{B}_{12}=16000 \mathrm{mg}$; niacin $=53000 \mathrm{mg}$; pantothenic acid $=13000 \mathrm{mg}$; vit. $\mathrm{K}=2500 \mathrm{mg}$; folic acid $=1000 \mathrm{mg}$; selenium $=250 \mathrm{mg}$; antioxidant $=100000 \mathrm{mg}$; manganese $=75000 \mathrm{mg}$; iron $=50000 \mathrm{mg} ;$ zinc $=$ $70000 \mathrm{mg}$; copper $=6500 \mathrm{mg}$; cobalt $=200 \mathrm{mg}$; iodine $=1500 \mathrm{mg}$.

${ }^{2}$ The numbers in parentheses refer to the composition analyzed ( $\left.\mathrm{N}^{*} 6.25\right)$.

${ }^{3}$ Digestible amino acid composition, $\mathrm{g} / \mathrm{kg}$. 
between regression equations can be tested to determine whether a common or separate regressions should be fitted to the data for each group or factor (genotype and replicated trial in this case). For an analysis of parallelism the first model to be fitted is a simple linear regression, ignoring the groups. Next, the model is extended to include a different constant term (or intercept) for each group, giving a set of parallel lines one for each group. Then, the final model has both a different constant and a different regression coefficient (or slope) for each group (Kaps \& Lamberson, 2004).

Table 2 Composition of diets used to determine the threonine requirements for maintenance of two strains of rooster

\begin{tabular}{|c|c|c|c|c|}
\hline \multirow[b]{2}{*}{ Ingredients } & \multicolumn{4}{|c|}{ Diets } \\
\hline & $\begin{array}{c}\text { Free N } \\
(1)^{1}\end{array}$ & $\begin{array}{c}\text { Concentrated } \\
(6)^{1}\end{array}$ & $\begin{array}{c}\text { Free N } \\
(1)^{2}\end{array}$ & $\begin{array}{c}\text { Concentrated } \\
(6)^{2}\end{array}$ \\
\hline Maize & ------- & 451.3 & ------- & 370 \\
\hline Soybean meal 45\% & ------- & 392.1 & ------- & 450 \\
\hline Starch & 400 & ------ & 400 & ------ \\
\hline Rice husk & 120 & ------ & 120 & ------ \\
\hline Sugar & 379 & ------ & 379.7 & ------ \\
\hline Soybean oil & 22.2 & 50.2 & 22.2 & 60.0 \\
\hline Dicalcium phosphate & 27.0 & 21.3 & 27.0 & 21.0 \\
\hline Limestone & 8.30 & 9.50 & 8.30 & 9.30 \\
\hline Salt & ------ & 8.00 & ------- & 8.10 \\
\hline Potassium chloride & 15.3 & ------ & 15.3 & ------- \\
\hline Sodium bicarbonate & 12.5 & ------ & 12.5 & ------- \\
\hline L-Lysine $\mathrm{HCl}(78.5 \%)$ & ------ & 5.40 & ------ & 6.00 \\
\hline DL-Methionine (98\%) & ------- & 10.1 & ------- & 11.7 \\
\hline L-Threonine $(90.6 \%)$ & ------ & 2.00 & ------ & 4.10 \\
\hline L-Tryptophan (93.3\%) & ------ & ----- & ------ & 3.00 \\
\hline L-Valine $(98 \%)$ & ------ & 11.0 & ------ & 12.0 \\
\hline L-Arginine (93.1\%) & ------ & 7.80 & ------ & 8.80 \\
\hline L-Isoleucine (98\%) & ------- & 7.90 & ------ & 9.00 \\
\hline L-Leucine $(98.5 \%)$ & ------ & 6.10 & ------ & 9.00 \\
\hline L-Phenylalanine (98\%) & ------ & 2.40 & ------- & 3.00 \\
\hline Choline chloride $70 \%$ & 10.0 & 5.00 & 5.00 & 5.00 \\
\hline Vitamin/mineral premix ${ }^{3}$ & 5.00 & 10.0 & 10.0 & 10.0 \\
\hline \multicolumn{5}{|l|}{ Nutrients calculated } \\
\hline Metabolizable energy (MJ/kg) & 13.0 & 13.0 & 13.0 & 13.0 \\
\hline Crude protein $(\%)$ & $2.10(39.5)^{4}$ & $249.7(269.7)^{3}$ & $2.10(25.0)^{3}$ & $278.0(282.9)^{3}$ \\
\hline Lysine digestible (\%) & ------ & 15.08 & ----- & 16.89 \\
\hline $\mathrm{M} \& \mathrm{C}$ digestible $(\%)$ & ------ & 15.84 & ------ & 17.74 \\
\hline Tryptophan digestible (\%) & ----- & 4.37 & ------- & 5.57 \\
\hline Threonine digestible $(\%)$ & ------ & 7.32 & ------- & 11.70 \\
\hline Arginine digestible $(\%)$ & ----- & 21.12 & ------ & 23.65 \\
\hline Valine digestible (\%) & ------ & 19.98 & ------- & 21.79 \\
\hline Phenylalanine digestible (\%) & ------ & 12.37 & ------ & 13.92 \\
\hline Isoleucine digestible (\%) & ------ & 16.44 & ------ & 18.44 \\
\hline Leucine digestible (\%) & ------ & 23.38 & ------ & 27.22 \\
\hline
\end{tabular}

${ }^{1}$ Contents as in Table 1. 
The concentration of each amino acid required to make up the 'ideal' protein for maintenance was calculated from the results by assuming that a bird requires $8 \mathrm{~g}$ of protein per unit of maintenance (Emmans $\&$ Fisher, 1986). The daily intake of each amino acid required per maintenance unit was divided by $8 \mathrm{~g}$.

\section{Results}

The mean live weight, empty body weight and body composition of the roosters used in the trials is given in Table 3.

Table 3 Mean live weight $(\mathrm{kg})$, empty body weight $(\mathrm{kg})$ and body composition ( $\mathrm{g} / \mathrm{kg}$ empty body weight) of Bovans White and Cobb roosters used in trials

\begin{tabular}{lcccccc}
\hline \multirow{2}{*}{ Strain used } & \multicolumn{5}{c}{ Body weight and composition } \\
& Live weight & $\begin{array}{c}\text { Empty body } \\
\text { weight }\end{array}$ & Water & Protein & Lipid & Ash \\
\hline Bovans White & 2.1 & 1.9 & 686 & 184 & 43.5 & 86.5 \\
Cobb & 5.7 & 5.5 & 663 & 199 & 57.0 & 81.0 \\
\hline
\end{tabular}

The range of daily allocations of each of the test amino acids, when converted to the three scales used to measure the daily intake $\left(\mathrm{mg} / \mathrm{kg}, \mathrm{mg} / \mathrm{kg}^{0.75}\right.$ and $\left.\mathrm{mg} / \mathrm{BP}_{\mathrm{m}}{ }^{0.73}\right)$, depended on the live weights and body protein weights of the birds used in the trials. The minimum allocation was, in all cases, zero and the maximum allocations, and hence intakes, when converted to these scales are given in Table 4.

Table 4 Maximum daily intakes by Bovans White and Cobb roosters of methionine \& cystine (M\&C) and threonine (THR) in each trial based on three scales of measurement

\begin{tabular}{clcc}
\hline \multicolumn{1}{c}{ Strain } & Scale used & M\&C & THR \\
\hline \multirow{3}{*}{ Bovans White } & $\mathrm{mg} / \mathrm{kg} \mathrm{d}^{0}$ & 138 & 127 \\
& $\mathrm{mg} / \mathrm{kg}^{0.75} \mathrm{~d}$ & 197 & 184 \\
& $\mathrm{mg} / \mathrm{BPm}^{0.73} \mathrm{~d}$ & 687 & 624 \\
$\mathrm{mg} / \mathrm{kg} \mathrm{d}^{\mathrm{C}}$ & 64 & 106 \\
& $\mathrm{mg} / \mathrm{kg}^{0.75} \mathrm{~d}$ & 103 & 172 \\
& $\mathrm{mg} / \mathrm{BPm}^{0.73} \mathrm{~d}$ & 346 & 584 \\
\hline
\end{tabular}

The results of the $\mathrm{N}$ balance trials with adult Bovans White and Cobb males to estimate the M\&C requirements for maintenance are presented in Table 5. The mean food intakes given in the table include the amount fed by intubation as well as the $\mathrm{N}$-free diet consumed voluntarily by the birds during the assay period, converted to a $\mathrm{g} / \mathrm{kg}$ basis. In most cases, the $\mathrm{N}$ excreted increased with $\mathrm{N}$ intake, resulting in increases in $\mathrm{N}$ balance with $\mathrm{N}$ supply. The daily intake of $\mathrm{M} \& \mathrm{C}$ was expressed using four different scales $\left(\mathrm{mg} / \mathrm{kg} \mathrm{BW}, \mathrm{mg} / \mathrm{bird}, \mathrm{mg} / \mathrm{kg} \mathrm{BW}{ }^{0.75}\right.$ and $\mathrm{mg} / \mathrm{BP}_{\mathrm{m}}{ }^{0.73}$ ) (Table 6). Because of the absence of differences $(P>0.05)$ between regression coefficients for the two strains used in the trials, only one equation is needed to describe the response of birds, independent of genotype when $\mathrm{mg} / \mathrm{BP}_{\mathrm{m}}{ }^{0.73}$ is used, and the results obtained are illustrated in Figure 1. The linear regression intersects the $x$ axis at an intake of $87.2( \pm 20.5) \mathrm{mg} / \mathrm{BP}_{\mathrm{m}}{ }^{0.73} \mathrm{~d}$, this being the maintenance requirement for $\mathrm{M} \& \mathrm{C}$, regardless of differences in body weight and composition. 
Table 5 Mean $( \pm \mathrm{SD})$ feed intake $(\mathrm{FI})$, methionine \& cysteine intake $(\mathrm{M} \& \mathrm{C})$, nitrogen intake $(\mathrm{NI})$, nitrogen excreted (NE), nitrogen balance (NB), and linear equation describing $\mathrm{N}$ balance on intake of $\mathrm{M} \& \mathrm{C}$ $\left(\mathrm{mg} / \mathrm{BP}_{\mathrm{m}}{ }^{0.73} \cdot \mathrm{ud}\right)$ in the trials with Bovans White and Cobb strains

\begin{tabular}{|c|c|c|c|c|c|}
\hline \multirow{2}{*}{ Strain } & \multirow{2}{*}{$\begin{array}{c}\mathrm{FI}^{1} \\
(\mathrm{~g} / \mathrm{kg} \mathrm{d})\end{array}$} & $\mathrm{M} \& \mathrm{C}$ & NI & $\mathrm{NE}$ & NB \\
\hline & & \multicolumn{4}{|c|}{$\mathrm{mg} / \mathrm{BP}_{\mathrm{m}}{ }^{0.73} \mathrm{~d}$} \\
\hline \multirow{8}{*}{ Bovans White } & $36.4 \pm 3.94$ & $0.00 \pm 0.0$ & $482 \pm 52.21$ & $778 \pm 51.49$ & $-296 \pm 101.84$ \\
\hline & $38.5 \pm 4.99$ & $59.8 \pm 1.50$ & $841 \pm 72.10$ & $768 \pm 28.67$ & $72.1 \pm 80.33$ \\
\hline & $45.0 \pm 4.69$ & $39.5 \pm 0.95$ & $712 \pm 42.22$ & $873 \pm 11.02$ & $-162 \pm 119.29$ \\
\hline & $41.2 \pm 5.54$ & $84.8 \pm 2.52$ & $1055 \pm 76.19$ & $1121 \pm 175.74$ & $-65.7 \pm 174.04$ \\
\hline & $45.5 \pm 4.16$ & $166 \pm 3.84$ & $1473 \pm 69.47$ & $1139 \pm 109.53$ & $334 \pm 154.71$ \\
\hline & $27.5 \pm 2.39$ & $334 \pm 10.11$ & $2139 \pm 56.24$ & $1523 \pm 181.09$ & $615 \pm 158.66$ \\
\hline & $39.1 \pm 2.97$ & $638 \pm 12.06$ & $4037 \pm 78.33$ & $2223 \pm 133.12$ & $1814 \pm 124.39$ \\
\hline & \multicolumn{5}{|c|}{$\mathrm{NB}=-303( \pm 70.7)+3.24( \pm 0.2)\left(\mathrm{r}^{2}=0.86\right)$} \\
\hline \multirow{7}{*}{ Cobb } & $24.6 \pm 1.4$ & $0.00 \pm 0.0$ & $368 \pm 18.3$ & $599 \pm 63.1$ & $-230 \pm 55.44$ \\
\hline & $38.7 \pm 1.7$ & $76.2 \pm 1.91$ & $853 \pm 20.9$ & $426 \pm 41.3$ & $428 \pm 46.22$ \\
\hline & $21.6 \pm 1.9$ & $55.3 \pm 2.07$ & $705 \pm 32.1$ & $803 \pm 76.0$ & $-97.7 \pm 85.24$ \\
\hline & $21.7 \pm 2.3$ & $120 \pm 4.05$ & $964 \pm 54.5$ & $749 \pm 67.0$ & $215 \pm 95.97$ \\
\hline & $21.0 \pm 1.6$ & $201 \pm 10.85$ & $1379 \pm 69.0$ & $1120 \pm 91.7$ & $259 \pm 69.14$ \\
\hline & $20.8 \pm 4.7$ & $263 \pm 10.46$ & $1744 \pm 138.8$ & $1070 \pm 117.1$ & $674 \pm 166.53$ \\
\hline & $21.6 \pm 3.3$ & $316 \pm 9.45$ & $1934 \pm 95.6$ & $1240 \pm 175.4$ & $695 \pm 223.69$ \\
\hline
\end{tabular}

$\mathrm{NB}=-247( \pm 76.2)+3.10( \pm 0.4)\left(\mathrm{r}^{2}=0.66\right)$

${ }^{1}$ Intake includes consumption of $\mathrm{N}$-free diet offered ad libitum.

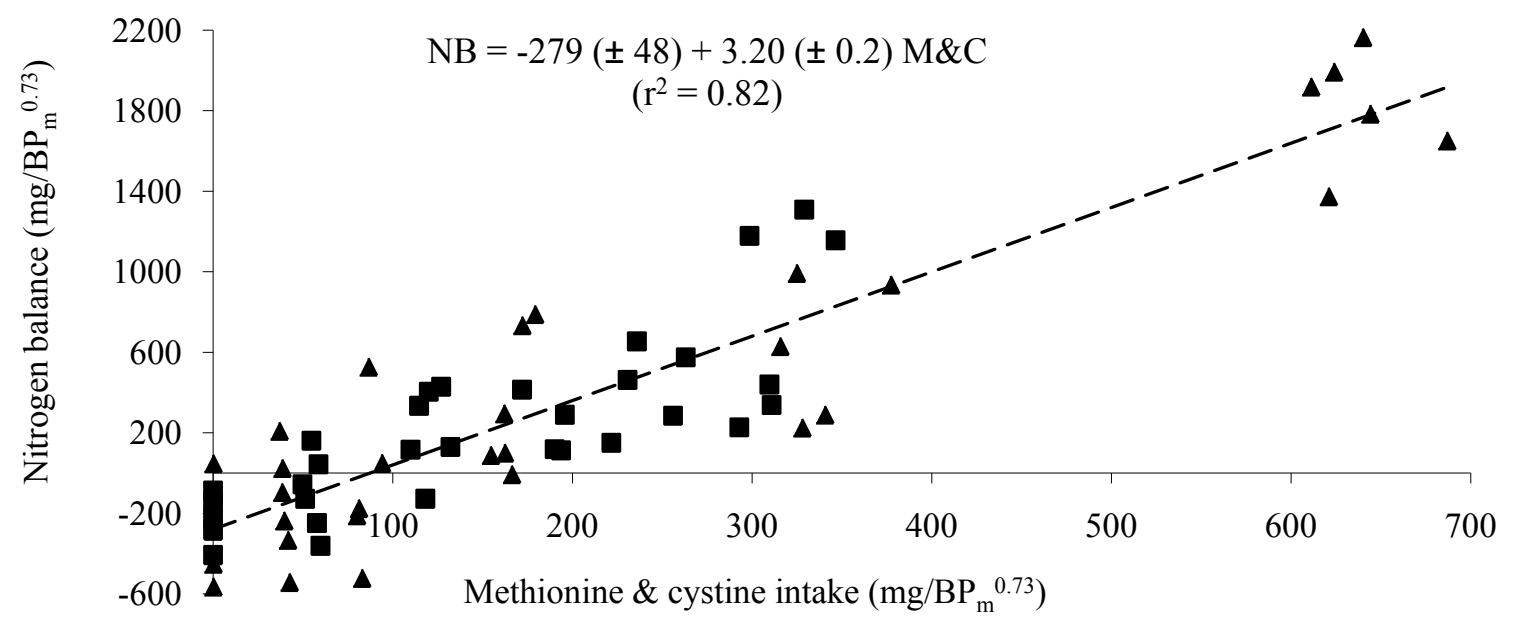

Figure 1 Graphical representation of the effect of increasing methionine $\&$ cysteine intake $\left(\mathrm{mg} / \mathrm{BP}_{\mathrm{m}}{ }^{0.73} \mathrm{~d}\right)$ on nitrogen balance in two strains of poultry (Bovans White $\boldsymbol{\Delta}$ and Cobb $\mathbf{\square}$ ). 
Table 6 Maintenance requirements for methionine \& cysteine (M\&C) based on four scales in terms of which the intake of these amino acids is described

\begin{tabular}{llcc}
\hline Daily M\&C intake & Regression equation & $\mathrm{r}^{2}$ & $\begin{array}{c}\text { Requirement estimated } \\
\text { by equation }\end{array}$ \\
\hline $\mathrm{mg} / \mathrm{bird}$ & $-174+2.924 \mathrm{X}$ & 0.72 & 59.5 \\
$\mathrm{mg} / \mathrm{kg} \mathrm{BW}^{1}$ & $-59.8+3.163 \mathrm{X}$ & 0.83 & 18.9 \\
$\mathrm{mg} / \mathrm{kg} \mathrm{BW}^{0.75}$ & $-81.4+3.201 \mathrm{X}$ & 0.82 & 25.5 \\
$\mathrm{mg} / \mathrm{BP}_{\mathrm{m}}{ }^{0.73} \mathrm{~d}^{2}$ & $-279+3.20 \mathrm{X}$ & 0.82 & 87.2 \\
\hline
\end{tabular}

${ }^{1}$ Body weight.

${ }^{2}$ Body protein at maturity.

Emmans \& Fisher (1986) suggested that birds need $8 \mathrm{~g}$ of 'ideal' protein daily per maintenance unit $\left(\mathrm{BP}_{\mathrm{m}}{ }^{0.73} \cdot \mathrm{u}\right)$. Thus, the proportion of $\mathrm{M} \& \mathrm{C}$ in the ideal protein for maintenance is $554 / 8=69.3$.

Table 7 Mean ( \pm SD) feed intake (FI), threonine intake (THR), nitrogen intake (NI), nitrogen excreted (NE), nitrogen balance (NB) and linear equation describing $\mathrm{N}$ balance on intake of $\mathrm{THR}\left(\mathrm{mg} / \mathrm{BP}_{\mathrm{m}}{ }^{0.73}\right.$.ud) in the trials with Bovans White and Cobb strains

\begin{tabular}{|c|c|c|c|c|c|}
\hline \multirow{2}{*}{ Strain } & \multirow{2}{*}{$\begin{array}{c}\mathrm{FI}^{1} \\
(\mathrm{~g} / \mathrm{kg} / \text { day })\end{array}$} & THR & NI & NE & NB \\
\hline & & \multicolumn{4}{|c|}{$\mathrm{mg} / \mathrm{BP}_{\mathrm{m}}^{0.73} \cdot \mathrm{ud}$} \\
\hline \multirow{7}{*}{ Bovans White } & $28.1 \pm 3.1$ & $0.0 \pm 0.0$ & $441 \pm 50.5$ & $644 \pm 39.1$ & $-203 \pm 36.8$ \\
\hline & $39.3 \pm 4.5$ & $96.4 \pm 1.25$ & $907 \pm 70.1$ & $565 \pm 131$ & $342 \pm 74.1$ \\
\hline & $31.9 \pm 5.7$ & $36.7 \pm 0.70$ & $705 \pm 89.4$ & $742 \pm 59.9$ & $-37.2 \pm 109$ \\
\hline & $29.6 \pm 3.3$ & $73.1 \pm 1.58$ & $831 \pm 50.2$ & $699 \pm 43.2$ & $132 \pm 73.9$ \\
\hline & $35.7 \pm 1.7$ & $144 \pm 1.39$ & $1365 \pm 2.90$ & $972 \pm 186$ & $393 \pm 170$ \\
\hline & $29.2 \pm 2.4$ & $287 \pm 5.89$ & $2269 \pm 60.9$ & $1087 \pm 77$ & $1182 \pm 43.8$ \\
\hline & $36.3 \pm 3.0$ & $577 \pm 12.97$ & $3705 \pm 82.7$ & $2084 \pm 195$ & $1620 \pm 184$ \\
\hline \multirow{8}{*}{ Bovans White } & $34.0 \pm 5.3$ & $0.0 \pm 0.0$ & $414 \pm 61.58$ & $779 \pm 171$ & $-364 \pm 186$ \\
\hline & $39.3 \pm 4.5$ & $96.4 \pm 1.25$ & $907 \pm 70.1$ & $565 \pm 131$ & $342 \pm 74.1$ \\
\hline & $30.9 \pm 4.8$ & $38.2 \pm 0.59$ & $719 \pm 44.2$ & $850 \pm 80.8$ & $-130 \pm 91.7$ \\
\hline & $35.7 \pm 5.2$ & $74.9 \pm 1.79$ & $852 \pm 47.1$ & $734 \pm 94.1$ & $117 \pm 97.6$ \\
\hline & $28.0 \pm 2.5$ & $152 \pm 3.22$ & $1413 \pm 35.1$ & $926 \pm 70.9$ & $487 \pm 88.8$ \\
\hline & $30.3 \pm 2.9$ & $292 \pm 5.56$ & $1849 \pm 49.1$ & $134 \pm 226$ & $509 \pm 168$ \\
\hline & $29.6 \pm 3.8$ & $584 \pm 5.34$ & $3544 \pm 81.6$ & $2238 \pm 331$ & $1306 \pm 230$ \\
\hline & \multicolumn{5}{|c|}{$\mathrm{NB}=-130( \pm 57.8)+2.91( \pm 0.2)\left(\mathrm{r}^{2}=0.74\right)$} \\
\hline \multirow{7}{*}{ Cobb } & $21.2 \pm 3.1$ & $0.0 \pm 0.0$ & $434 \pm 55.5$ & $739 \pm 69.8$ & $-305 \pm 109$ \\
\hline & $32.6 \pm 3.6$ & $95.3 \pm 2.49$ & $873 \pm 61.7$ & $405 \pm 59.7$ & $468 \pm 83.2$ \\
\hline & $17.0 \pm 2.0$ & $52.6 \pm 2.46$ & $530 \pm 42.1$ & $945 \pm 87.2$ & $-415 \pm 105$ \\
\hline & $15.9 \pm 0.8$ & $212 \pm 9.33$ & $1146 \pm 37.3$ & $1095 \pm 175$ & $51.3 \pm 144$ \\
\hline & $22.6 \pm 1.6$ & $324 \pm 13.1$ & $1605 \pm 58.7$ & $1008 \pm 164$ & $597 \pm 209$ \\
\hline & $14.2 \pm 3.2$ & $416 \pm 7.74$ & $1893 \pm 104$ & $1379 \pm 384$ & $514 \pm 269$ \\
\hline & $18.9 \pm 3.5$ & $542 \pm 15.9$ & $2296 \pm 111$ & $1597 \pm 204$ & $698 \pm 196$ \\
\hline
\end{tabular}

\footnotetext{
${ }^{1}$ Intake includes consumption of $\mathrm{N}$-free diet offered ad libitum.
} 
The results of the three THR trials, two with Bovans White and one with Cobb, are given in Table 7. As with the M\&C data, the daily intake of THR was expressed using four different scales (mg/bird, $\mathrm{mg} / \mathrm{kg}$ $\mathrm{EBW}, \mathrm{mg} / \mathrm{kg} \mathrm{EBW}^{0.75}$ and $\mathrm{mg} / \mathrm{BP}_{\mathrm{m}}{ }^{0.73}$ ) (Table 8$)$, and in this case also there were no differences $(P>0.05)$ between regression coefficients for the two strains used in the trials, thus only one equation is needed to describe the response of birds, independent of genotype when $\mathrm{mg} / \mathrm{BP}_{\mathrm{m}}{ }^{0.73}$ is used. The results obtained in the THR trials are illustrated in Figure 2. The linear regression intersects the $\mathrm{x}$ axis at an intake of $75.5( \pm 29.8)$ $\mathrm{mg} / \mathrm{BP}_{\mathrm{m}}{ }^{0.73}$ day, this representing the maintenance requirement for THR.

Table 8 Maintenance requirements for threonine (THR) based on four scales in terms of which the intake of these amino acids is described

\begin{tabular}{lccc}
\hline \multicolumn{1}{c}{ Daily THR intake } & Equations & $\mathrm{r}^{2}$ & $\begin{array}{c}\text { Requirement estimated } \\
\text { by equation }\end{array}$ \\
\hline $\mathrm{mg} / \mathrm{bird}$ & $-82.2+1.831 \mathrm{X}$ & 0.45 & 44.9 \\
$\mathrm{mg} / \mathrm{kg} \mathrm{BW}^{1}$ & $-45.8+2.686 \mathrm{X}$ & 0.71 & 17.1 \\
$\mathrm{mg} / \mathrm{kg} \mathrm{BW}^{0.75}$ & $-54.7+2.498 \mathrm{X}$ & 0.60 & 22.0 \\
$\mathrm{mg} / \mathrm{BP}_{\mathrm{m}}{ }^{0.732}$ & $-191+2.53 \mathrm{X}$ & 0.60 & 44.7
\end{tabular}

\footnotetext{
${ }^{1}$ Body weight.

${ }^{2}$ Body protein at maturity.
}

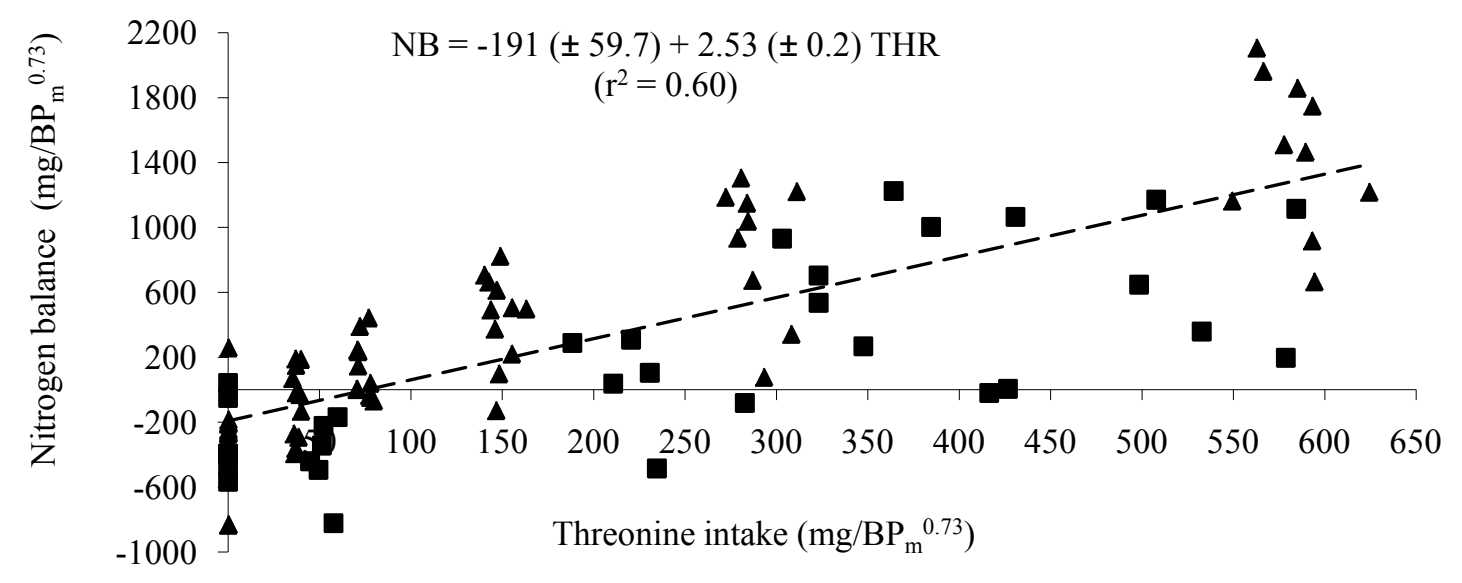

Figure 2 Graphical representation of the effect of increasing threonine intake $\left(\mathrm{mg} / \mathrm{BP}_{\mathrm{m}}{ }^{0.73} \mathrm{~d}\right)$ on nitrogen balance in two strains of poultry (Bovans White $\boldsymbol{\Delta}$ and Cobb $\boldsymbol{\square}$ ).

\section{Discussion}

There is no standard acceptable methodology for measuring the amino acid requirement for maintenance. Limitations to the early methods used have been discussed and addressed by Gous et al. (1984) and Burnham \& Gous (1992), and it is the method suggested by these authors that was used in the present exercise. As a result of differences in methodology it is not surprising that the requirement of M\&C for maintenance presented here $\left(25.5 \mathrm{mg} / \mathrm{kg}^{0.75}\right)$ is lower than that suggested by Leveille et al. (1960), who estimated a daily intake of $143 \mathrm{mg} / \mathrm{kg}^{0.75}$, and higher than the value published by Edwards \& Baker (1999) which was $9.4 \mathrm{mg} / \mathrm{kg}^{0.75} \mathrm{~d}$. Leveille et al. (1960) used sexually mature roosters, as in the present trials, but defined the maintenance requirement as the lowest amount of amino acid that would maintain the same $\mathrm{N}$ balance as observed on a whole egg protein diet, whereas Edwards \& Baker (1999) used growing chickens 
fed purified diets, and applied a comparative slaughter method to quantify the deposition of body protein and amino acids.

An additional area in which studies differ is that in the present study excreta were collected once daily in trays, which prevented contamination from feathers, skin and feed, and reduced the amount of $\mathrm{N}$ lost as ammonia, which may explain the lower value found for M\&C than by Leveille et al. (1960). Also, according to the methodology of Nonis \& Gous (2008), giving the birds free access to a N-free diet enables them to meet their requirement for essential trace nutrients, but more importantly, their energy demand is met without having to deaminate body protein, which would otherwise have the effect of increasing $\mathrm{N}$ output.

Metabolic body weight has in the past been the preferred scale on which to base maintenance requirements, but convincing arguments by Taylor (1980) and Emmans (1981) suggested that maintenance should be scaled according to two formal genetic size-scaling rules, one for time variables based on the concept of metabolic age, and the other for cumulated growth variables based on the degree of maturity. Genetic comparisons made at the same metabolic age or at the same degree of maturity are independent of adult size. By averaging over genotypes at each metabolic age or degree at maturity, mean size-scaled growth curves are obtained which provide a unified description of avian and mammalian growth and the maintenance requirements should thus be based on this scale. Emmans (1981) suggested a "maintenance unit' $\left(\mathrm{BP}_{\mathrm{m}}{ }^{0.73} . \mathrm{u}\right)$ based on this theory. This scale has the added advantage of excluding body lipid from the unit of measurement: Expressing maintenance requirements on the basis of body weight or metabolic weight has been questioned because there is no demand for amino acids for the maintenance of lipid reserves (Emmans \& Oldham, 1988; Burnham \& Gous, 1992; Gous, 2007) which can vary considerably even among individuals with similar body weight (Emmans \& Fisher, 1986; Emmans \& Oldham, 1988; Burnham \& Gous, 1992; Nonis \& Gous, 2008). Thus, when comparing maintenance requirements between birds of different body weight and composition, body protein content of the bird at the time and in relation to its mature protein weight is preferred. Because the birds used in the present trials were mature the maintenance unit can be written as $\mathrm{BP}_{\mathrm{m}}{ }^{0.73}$ as $\mathrm{u}$, the degree of maturity is 1 in this case.

In both amino acid assays the Bovans White strain showed less variation between individuals than did the Cobb strain ( $\mathrm{r}^{2}$ of 0.86 vs. 0.66 for $\mathrm{M} \& \mathrm{C}$ and $0.74 v s .0 .55$ for THR). Variation between observations based on the four different scales used to express maintenance requirements differed little, other than when these were expressed per bird $\left(\mathrm{r}^{2}\right.$ of 0.72 vs. $0.83,0.82$ and 0.82 in the case of $\mathrm{M} \& \mathrm{C}$; and 0.45 vs. $0.71,0.60$ and 0.60 for THR). The lower variation between individual $\mathrm{N}$ balance results for the M\&C assays compared with those for THR is well illustrated in Figures 1 and 2 where the variation at the highest M\&C intakes is considerably less than at the highest TR intakes. The wide gap between the two highest intakes of M\&C and the small variation between the observations at the highest intake of this amino acid have the effect of applying high leverage to the regression as well as decreasing the error variance.

Because Leveille et al. (1960), Edwards \& Baker (1999) and Nonis \& Gous (2008) did not express the requirements for maintenance using the same scales as were applied here, we used their data, where available, to construct tables in which their results and ours could be compared, using all four scales for expressing maintenance requirements for M\&C (Table 9) and for THR (Table 10). As an example of these calculations, consider the maintenance requirement for M\&C estimated by Leveille et al. (1960) of 113 $\mathrm{mg} / \mathrm{kg} \mathrm{d}$, and a mean body weight of $2.55 \mathrm{~kg}$ : the roosters in that trial required $288 \mathrm{mg} \mathrm{M \& C}$ for maintenance/d. With an estimated (unpublished) body protein content of $160 \mathrm{~g} / \mathrm{kg}$, resulting in a $\mathrm{BP}_{\mathrm{m}}$ of $0.408 \mathrm{~kg}$, and since they were mature $(\mathrm{u}=1)$, the $\mathrm{M} \& \mathrm{C}$ for maintenance on the basis of body protein is $288 / 0.408^{0.73}=554 \mathrm{mg} / \mathrm{d}$.

When a maintenance unit, as defined above, was used for comparative purposes our results for M\&C (87.2 $\mathrm{mg} /$ maintenance unit) were again higher than the estimate of Edwards \&Baker (1999) (35 $\mathrm{mg} / \mathrm{BP}_{\mathrm{m}}{ }^{0.73} \cdot \mathrm{u} /$ day or $4.37 \mathrm{~g} \mathrm{M} \& \mathrm{C} / \mathrm{kg}$ ideal protein) and lower than that of Leveille et al. (1960) of 548 $\mathrm{mg} / \mathrm{BP}_{\mathrm{m}}{ }^{0.73} . \mathrm{u} /$ day $(68.6 \mathrm{~g} \mathrm{M} \& \mathrm{C} / \mathrm{kg}$ ideal protein). Edwards \& Baker (1999) used growing birds and measured carcass composition, which enabled this calculation to be made, so in this case the difference in estimated requirement was most likely due to differences in the feed composition and feeding practices used. The estimate published by Leveille et al. (1960) is considerably different from ours, which is partly due to their not estimating $\mathrm{M} \& \mathrm{C}$ requirement directly, but also because they did not measure or publish the body protein 
Table 9 A comparison of the methionine \& cysteine $\left(M \& C_{m}\right)$ requirement for maintenance expressed in different units, obtained in this and previous studies

\begin{tabular}{|c|c|c|c|c|c|c|c|}
\hline & \multirow{2}{*}{$\begin{array}{l}\mathrm{MP}^{1} \\
(\mathrm{~kg})\end{array}$} & \multirow{2}{*}{$\begin{array}{c}\mathrm{BP}_{\mathrm{m}}{ }^{2} \\
(\mathrm{~kg})\end{array}$} & \multicolumn{4}{|c|}{$M \& C_{m}$ (mg/unit d) } & \multirow{2}{*}{$\begin{array}{l}\mathrm{PIM}^{4} \\
(\mathrm{~g} / \mathrm{kg})\end{array}$} \\
\hline & & & bird & $\mathrm{kg}$ & $\mathrm{kg}^{0.75}$ & $\mathrm{BP}_{\mathrm{m}}^{0.73} \cdot \mathrm{u}^{3}$ & \\
\hline Bovans White & 2.02 & 0.371 & 45.4 & 22.5 & 26.8 & 93.5 & 11.7 \\
\hline Cobb & 5.54 & 1.100 & 80.6 & 15.7 & 23.7 & 79.7 & 9.96 \\
\hline General $^{5}$ & 3.78 & 0.723 & 59.5 & 18.9 & 25.5 & 87.2 & 10.9 \\
\hline Leveille et al. (1960) & 2.55 & 0.408 & 288 & 113 & 142 & 554 & 69.3 \\
\hline Edwards \& Baker (1999) & 0.19 & 0.030 & 2.70 & 14.2 & 9.4 & 35.0 & 4.37 \\
\hline
\end{tabular}

${ }^{1} \mathrm{MP}=$ empty body weight at maturity (feather-free body); ${ }^{2} \mathrm{BP}_{\mathrm{m}}=$ body protein weight at maturity; ${ }^{3} \mathrm{u}=\mathrm{BP}_{\mathrm{t}} / \mathrm{BP}_{\mathrm{m}}=1$;

${ }^{4} \mathrm{PIM}=$ concentration of $\mathrm{M} \& \mathrm{C}$ in ideal protein for maintenance, assuming concentrations of crude protein $(\mathrm{CP}) 184$, 199,160 and $160 \mathrm{~g} / \mathrm{kg}$, respectively (for feather-free body); ${ }^{5}$ Requirements considering a mean bodyweight between two strains of $3.78 \mathrm{~kg}$ and average body protein content of $191 \mathrm{~g} / \mathrm{kg}$.

content of the birds with which they worked, so the value used here was an estimate. It is likely that the basis on which these authors calculated maintenance requirements (using the composition of egg protein as the ideal protein) necessarily leads to overestimation of the requirement, as proposed by Gous et al. (1984).

Regarding the determination of the threonine requirement for maintenance, it is well known that mucin production increases when the bird is challenged by certain diseases (Ball et al., 1999) and this can increase the threonine requirement for maintenance, but in these trials the additional amount of threonine needed for this purpose was not measured as these birds remained healthy throughout the trials.

The estimated THR requirement for maintenance obtained with the two strains used in these trials compare more favourably with those from other studies in the literature (Table 10) than is the case with the estimates for M\&C. The results published by Leveille \& Fisher (1960), particularly, conform far more closely than those by the same laboratory in the case of M\&C: in the case of THR their estimate of 68.3 is very similar to the values obtained here for Cobb (50) and those by Nonis \& Gous $\left(70 \mathrm{mg} / \mathrm{kg}^{0.75} / \mathrm{d}\right)$ whereas their estimate of the $M \& C$ requirement was 6 times greater than the present estimate. Similarly, the amount of THR in ideal protein is calculated to be 33 using Leveille \& Fisher's (1960) values, compared with 21 in the present trials and $34 \mathrm{~g}$ THR/kg of ideal body protein suggested by Nonis \& Gous (2008).

Table 10 Requirements of threonine for maintenance $\left(\mathrm{THR}_{\mathrm{m}}\right)$ expressed in different units, obtained in this and previous studies

\begin{tabular}{|c|c|c|c|c|c|c|c|}
\hline & \multirow{2}{*}{$\begin{array}{l}\mathrm{MP}^{1} \\
(\mathrm{~kg})\end{array}$} & \multirow{2}{*}{$\begin{array}{c}\mathrm{BP}_{\mathrm{m}}{ }^{2} \\
(\mathrm{~kg})\end{array}$} & \multicolumn{4}{|c|}{$\mathrm{THR}_{\mathrm{m}}$ (mg/unit d) } & \multirow{2}{*}{$\begin{array}{c}\mathrm{PIM}^{4} \\
(\mathrm{~g} / \mathrm{kg})\end{array}$} \\
\hline & & & Bird & $\mathrm{kg}$ & $\mathrm{kg}^{0,75}$ & $\mathrm{BP}_{\mathrm{m}}^{0,73} \cdot \mathrm{u}^{3}$ & \\
\hline Bovans White & 2.11 & 0.39 & 22.2 & 10.6 & 12.9 & 44.7 & 5.58 \\
\hline Cobb & 5.78 & 1.15 & 188 & 32.1 & 50.0 & 168 & 21.1 \\
\hline General $^{5}$ & 3.95 & 0.76 & 44.9 & 17.1 & 21.9 & 75.5 & 9.44 \\
\hline Nonis \& Gous (2008) & 2.50 & 0.40 & 140 & 56.0 & 70.4 & 273 & 34.2 \\
\hline Leveille \& Fisher (1960) & 2.38 & 0.38 & 131 & 55.0 & 68.3 & 265 & 33.1 \\
\hline
\end{tabular}

${ }^{1} \mathrm{MP}=$ body weight at maturity (feather-free body); ${ }^{2} \mathrm{BP}_{\mathrm{m}}=$ body protein weight at maturity; ${ }^{3} \mathrm{u}=\mathrm{BP}_{\mathrm{t}} / \mathrm{BP}_{\mathrm{m}}=1$;

${ }^{4} \mathrm{PIM}=$ concentration of THR in ideal protein for maintenance, assuming concentrations of crude protein $(\mathrm{CP}) 184$, 199,160 and $160 \mathrm{~g} / \mathrm{kg}$, respectively (for feather-free body); ${ }^{5}$ Requirements considering a mean liveweight between the two strains of $3.95 \mathrm{~kg}$ and average body protein content of $191 \mathrm{~g} / \mathrm{kg}$. 
Emmans (1989) estimated this latter value to be $42 \mathrm{~g}$ THR $/ \mathrm{kg}$ of ideal body protein. One reason for the closer agreement with THR than with M\&C is the difficulty associated with the chemical analysis of M\&C in body tissue, feedstuffs and in mixed feeds. This has been discussed comprehensively by Denison \& Gous (1984) and is related to the need to use a different hydrolysis method when analysing these amino acids than is used for most of the others in a feed or carcass sample.

The maintenance requirement of birds for each of the amino acids is of great importance when determining the amino acid requirement of a broiler or laying hen using the factorial approach (Emmans \& Fisher, 1986), which requires an estimate of the requirement for growth or egg production and another for maintenance. The amount required for maintenance is not trivial: as the bird grows the maintenance requirement becomes a greater proportion of the total required, so the accurate estimation of this component is essential if nutritional decisions are to be made on the basis of these calculations. This is especially the case when simulation models are used for predicting food intake and consequent performance (Nonis \& Gous, 2008).

\section{Conclusion}

Using three scales for expressing maintenance requirements, the daily amount of $\mathrm{M} \& \mathrm{C}$ required was estimated to be $19 \mathrm{mg} / \mathrm{kg} \mathrm{BW}, 26 \mathrm{mg} / \mathrm{kg} \mathrm{BW}^{0.75}$, and $87 \mathrm{mg} / \mathrm{BP}_{\mathrm{m}}{ }^{0.73}$ and the concentration of M\&C in ideal protein was estimated to be $11 \mathrm{~g} / \mathrm{kg}$ body protein. The equivalent daily values for THR for maintenance were estimated to be $17 \mathrm{mg} / \mathrm{kg} \mathrm{BW}, 22 \mathrm{mg} / \mathrm{kg} \mathrm{BW}^{0.75}$, and $76 \mathrm{mg} / \mathrm{BP}_{\mathrm{m}}^{0.73}$ with the concentration of THR in ideal protein being $9.4 \mathrm{~g} / \mathrm{kg}$ body protein.

The $\mathrm{M} \& \mathrm{C}$ requirements for maintenance of adult roosters measured in the trials reported here differed substantially from those measured previously, but it is likely that these arise as a result of differences in the methodology used in the various trials. THR requirements measured here were similar to previous estimates because a similar methodology was used.

\section{Acknowledgments}

The Fundação de Apoio à Pesquisa do Estado de São Paulo (FAPESP) for financing the research and the research grant.

\section{References}

AOAC, 1990. Association of Official Analytical Chemists. 15 ed. Official Methods of Analysis. Washington D.C., USA. $1141 \mathrm{p}$.

Baker, D.H., 1991. Partitioning of nutrients for growth and other metabolic functions: efficiency and priority considerations. Poult. Sci. 70, 1797-1805.

Baker, D.H., Becker, D.E., Norton, H.W., Jensen, A.H. \& Harmon, B.G., 1966. Quantitative evaluation of the threonine, isoleucine, valine and phenylalanine needs of adult swine for maintenance. J. Nutr. 88, 391-396.

Ball, R.O., Law, G., Bertolo, R.F.P. \& Pencharz, P.B., 1999. Adequate oral threonine is critical for mucin production and mucosal growth by neonatal piglet gut. In: Proceedings of the VIIIth International Symposium on Protein Metabolism and Nutrition. Eds Lobley, G.E., White, A. \& MacRae, J.C., EAAP Publication vol. 96, 31.

Bequette, B.J., 2003. Amino Acid Metabolism in Animals: an Overview. In: Absorption and utilization of amino acids. Ed. D’Mello, J.F.P., Wallingford: CABI Publishing. pp. 87-102.

Burnham, D. \& Gous, R.M., 1992. Isoleucine requirements of the chicken: requirement for maintenance. Br. Poult. Sci. 33, 59-69.

Dennison, C. \& Gous, R.M., 1984. Hydrolysis conditions for the analysis for sulphur amino acids in feedstuffs. S. Afr. J. Anim. Sci. 14, 64-69.

D’Mello, J.F.P., 2003. Amino Acids as Multifunctional Molecules. In: Absorption and Utilization of Amino Acids. Ed. D’Mello, J.F.P., Wallingford: CABI Publishing. pp. 1-14.

Edwards, H.M. \& Baker, D.H., 1999. Maintenance sulfur amino acid requirements of young chicks and efficiency of their use for accretion of whole-body sulfur amino acids and protein. Poult. Sci. 78, 1418-1423. 
Emmans, G.C., 1981. Computer simulation in poultry nutrition. In: $3^{\text {rd }}$ European Symposium on Poultry Nutrition. pp. 1-21.

Emmans, G.C., 1989. The growth of turkey. In: Recent Advances in Turkey Science. Eds Nixey, C. \& Grey, T.C., Butterworths, London. pp. 135-166.

Emmans, G.C. \& Fisher, C., 1986. Problems in nutritional theory. In: Nutrient Requirements of Poultry and Nutritional Research. Eds Fisher, C. \& Boorman, K.N., London, Butterworths. pp. 9-39.

Emmans, G.C. \& Oldham, J.D., 1988. Modelling of growth and nutrition in different species. In: Modelling of Livestock Production Systems. Eds Korver, S. \& Van Arendonk, J.A.M., Kluwer Academic Publishers, Amsterdam. pp. 13-21.

Fisher, C. \& Scougal, R.K., 1982. A note on the amino acid composition of the turkey. Br. Poult. Sci. 23, 233-237.

Gous, R.M., 2007. Methodologies for modeling energy and amino acid responses in poultry. Braz. J. Anim. Sci. 36, 263-274.

Gous, R.M., Fisher, C. \& Broadbent, L.A., 1984. Measurement of the amino acid requirement for maintenance of adult cockerels. XVII Wrld's Poult. Congr., Helsinki, Finland.

Gous, R.M., Emmans, G.C., Broadbent, L.A. \& Fisher, C., 1990. Nutritional effects on the growth and fatness of broilers. Br. Poult. Sci. 31, 495-505.

Graber, G. \& Baker, D.H., 1971. Sulfur amino acid nutrition of the growing chick: quantitative aspects concerning the efficacy of dietary methionine, cysteine and cystine. J. Anim. Sci. 33, 1005-1011.

Heger, J., Van Phung, T. \& Krizova, L., 2002. Efficiency of amino acid utilization in the growing pig at suboptimal levels of intake: lysine, threonine, sulphur amino acids and tryptophan. J. Anim. Physiol. Anim. Nutr., Berlin 86, 153-165.

Kalbande, V.H., Ravikanth, K., Maini, S. \& Rekhe, D.S., 2009.Methionine supplementation options in poultry. Int. J. Poult. Sci. 8, 588-591.

Kalinowski, A., Moran, E.T. \& Wyatt, C.L., 2003. Methionine and cystine requirements of slow- and fastfeathering broiler males from three to six weeks of age. Poult. Sci. 82, 1428-1437.

Kaps, M. \& Lamberson, W.R., 2004. Biostatistics for Animal Science. Wallingford: CABI Publishing. $445 \mathrm{p}$.

Kyriazakis, I., Emmans, G.C. \& McDaniel, R., 1993. Whole body amino acid composition of the growing pig. J. Sci. Fd. Agric. 62, 29-33.

Leveille, G.A. \& Fisher, H., 1960. Amino acid requirements for maintenance in the adult rooster III. The requirements for leucine, isoleucine, valine and threonine, with reference also to the utilization of the d-isomers of valine, threonine and isoleucine. J. Nutr. 70, 135-140.

Leveille, G.A., Shapiro, R. \& Fisher, H., 1960. Amino acid requirements for maintenance in the adult rooster IV. The requirements for methionine, cystine, phenylalanine, tyrosine and tryptophan; the adequacy of the determined requirements. J. Nutr.72, 8-15.

Lewis, A.J., 2003.Methionine-cystine relationships in pig nutrition. In: Absorption and Utilization of Amino Acids. Ed. D’Mello, J.F.P., Wallingford: CABI Publishing. pp. 143-156.

Martin, P.A., Bradford, G.D. \& Gous, R.M., 1994. A formal method of determining the dietary amino acid requirements of laying type pullets during their growing periods. Br. Poult. Sci. 35, 709-724.

Moran, E.T., 1994. Response of broiler strains differing in body fat to inadequate methionine: live performance and processing yields. Poult. Sci.73, 1116-1126.

Moughan, P.J., 2003.Simulating the partitioning of dietary amino acids: New directions. J. Anim. Sci. 81, E60-E67.

Nitsan, Z., Dvorin, A. \& Nir, I., 1981. Composition and amino acid content of carcass, skin and feathers of the growing gosling. Br. Poult. Sci. 22, 79-84.

Nonis, M.K. \& Gous, R.M., 2008. Threonine and lysine requirements for maintenance in chickens. S. Afr. J. Anim. Sci. 38, 75-82.

Owens, F.N. \& Pettigrew, J.E., 1989. Subdividing amino acid requirements into portions for maintenance and growth. In: Absorption and Utilization of Amino Acids. Ed. Friedman, M., Boca Raton: CRC Press. pp. 15-30.

Rostagno, H.S., Albino, L.F.T., Donzele, J.L., Gomes, P.C., Oliveira, R.F.M., Lopes, D.C., Ferreira, A.S. \& Barreto, S.L.T., 2005. Tabelas brasileiras para aves e suínos: composição de alimentos e exigências 
nutricionais. 2nd. ed. Viçosa, MG: Departamento de Zootecnia, Universidade Federal de Viçosa. (in Portuguese).

Sakomura, N.K. \& Coon, C., 2003. Amino acid requirements for maintenance of broiler breeder pullets. In: European Symposium on Poultry Nutrition, Lillehammer 14, 280-281.

Sakomura, N.K. \& Rostagno, H.S., 2007. Métodos de pesquisaemnutrição de monogástricos. Jaboticabal: Funep. 283 p. (in Portuguese).

SAS, 2002. SAS user's guide: statistics. Statistical Analysis System Institute, Cary, N.C., USA.

Siqueira, J.C., 2009. Estimativas das exigências de lisina de frangos de corte pelos métodos dose resposta e fatorial. 178 f. Tese (Doutorado em Zootecnia) - Universidade Estadual Paulista, Faculdade de Ciências Agrárias e Veterinárias, Jaboticabal. (in Portuguese).

Stoll, B., 2003. Intestinal uptake and metabolism of threonine: Nutritional impact. Adv. Pork Prod., Edmonton 17, 257-263.

Summers, J.D., Spratt, D. \& Atkinson, J.L., 1992. Broiler weight gain and carcass composition when fed diets varying in amino acid balance, dietary energy and protein level. Poult. Sci. 71, 263-273.

Wylie, L.M., Robertson, G.W., Macleod, M.G. \& Hocking, P.M., 2001. Effect of ambient temperature and restricted feeding on the growth of feathers in growing turkeys. Br. Poult. Sci. 42, 449-455.

Young, R.J., Norris, L.C. \& Heuser, G.F., 1955. The chick's requirement for folic acid in the utilization of choline and its precursors betaine and methylaminoethanol. J. Nutr. 55, 362-365. 